\title{
Determination and Toxicological Effects of Some Heavy Metals in Surface Water from the Niger Delta, Nigeria.
}

\author{
Nwineewii, J. D ${ }^{1}$ And Edem C.A ${ }^{2}$ \\ ${ }^{1}$ department Of Chemistry Ignatius Ajuru University Of Education Rumuolumeni, Port Harcourt, Nigeria \\ ${ }^{2}$ Department Of Pure And Applied Chemistry University Of Calabar, Calabar, Nigeria
}

\begin{abstract}
The Niger Delta is the hub of industrial establishments in Nigeria. With the concentration of industries in this part of the country, it is believed by many that the environment may have been impactedwith heavy metals as a result of wastes generated by these industries. This study was necessitated by the desire to find out the current levels and toxic effects of some of the metals in surface water from the Niger Delta. To actually verify this claim, surface water sample were collected from ten locations for a period of eight months. The surface water collected were first acid treated with $2 \mathrm{ml}$ concentrated nitric acid (assaying 100\%) and taken to the laboratory where the concentrations of the various metals were determined using Atomic Absorption Spectrophotometer. The results of the analysis were as follows: $\mathrm{Cd}(0.003 \mathrm{Mg} / \mathrm{l}), \mathrm{Cr}(0.172 \mathrm{Mg} / \mathrm{l}), \mathrm{Pb}$ $(0.057 \mathrm{Mg} / \mathrm{l}), \mathrm{Fe}(0.403 \mathrm{Mg} / \mathrm{l}), \mathrm{Zn}(0.218 \mathrm{Mg} / \mathrm{l}), \mathrm{Ni}(0.816 \mathrm{Mg} / \mathrm{l}), \mathrm{Mn}(0.725 \mathrm{Mg} / \mathrm{l})$ and $\mathrm{Cu}(0.011 \mathrm{Mg} / \mathrm{l})$. From these results, it was seen that the concentrations of the metals were within the national and international recommended limits; however some of these metals are known to be toxic even at low concentrations. It was also observed from the results that the concentrations of the metals in the dry season were higher than those of the wet season.
\end{abstract}

Key words: Determination, Toxicology, Effects, Heavy Metals, Niger Delta, Surface Water.

\section{Introduction}

Trace metals enter the environment as a result of natural processes and human activities via rivers, land run-off, dumping, the atmosphere and the seabed (Opuene, 2004). Major natural sources are weathering of rocks, release from terrestrial and dissolution from marine sediments. The dominant inputs for most trace metals are through rivers and land run-off.Metals, when introduced into the aquatic environment, do not remain in water column. They may be concentrated in the surface film or become absorbed onto suspended particulate matter so that they precipitate out on the bottom. Although sediments are sinks, trace metals may re-enter the water column by physical, chemical and biological processes. In this way, the sediments serve as a buffer and may be able to keep the metal concentrations in water and biota above the background levels long after their input have been discontinued (Binning and Baird, 2001).Public attention has been drawn in recent years to the contamination of the environments by these inorganic species. The prime target in the research on the environment today is to determine the concentrations of these heavy metals as well as elucidate the chemical forms in which they appear (Onuoha, 1996).

In natural aquatic ecosystems, metals occur at low concentrations, normally, at the nanogram to microgram per litre level. In recent times, however, metal contamination, especially the heavy metals in excess of natural loads has become a problem of increasing concern. This situation has arisen as a result of population increase, urbanization, and expansion of industrial activities, exploration of natural resources, extension of irrigation and other modern agricultural practices as well as the lack of environmental regulations (Bineyet al., 1994). Unlike other pollutants such as petroleum hydrocarbons, which may visibly be prevalent in the environment, trace metals may accumulate unnoticed to toxic levels. Problems associated with trace metal contamination were first highlighted in industrial discharges especially through incidents of mercury and cadmium pollution in Sweden and Japan (Kurdland, 1960). The likely major source of most of these chemicals is the industrial wastes being discharged into city sewage system. Therefore, there is growing awareness of the need for rational management of aquatic resources including control of waste discharges into the environment. This becomes even more important in view of the expected increase in industrial and urban activities in all parts of the country. The discovery of the accumulation of some contaminants has prompted investigations of the accumulation of others leading to a better understanding of the cycling of these elements in our environment. Advances in instrumental analytical techniques have now enabled scientists not only to quantify even ultra-trace constituents in systems, such as platinum-group elements (PGEs) in ecosystems, or heavy metals, such as lead or antimony, at lowest background levels, but also to perform speciation analysis for some metal(loids) such as arsenic, antimony, and mercury (Hirner and Hippler, 2011). 


\section{Water sample collection for heavy metals analyses}

Water sample were collected from the following communities vizAgbonchia, Aleto, Abam, Ogan and Okrika Riverin the South Eastern part of Rivers State of the Niger Delta, Nigeria. The specific sampling points were location I(Agbonchia1),location2(Agbonchia2), location3(petrochemicals),location4(Dredging), location5(slaughter), location6(Railway), location7(NNPC QTRS), location8(Abam), location9(Ogan), location10(Okrika River). Sampling of surface water was carried out monthly (July 2010-February 2011) for the determination of the concentration of heavy metals $(\mathrm{Cr}, \mathrm{Cu}, \mathrm{Cd}, \mathrm{Ni}, \mathrm{Zn}, \mathrm{Fe}, \mathrm{Mn}, \mathrm{Pb}$ ). The sample containers (1L plastic bottles) for heavy metals analyses were first rinsed with nitric acid and upon collection of the water sample was treated with $2 \mathrm{ml}$ concentrated nitric acid (assaying 100\%) prior to storage in cool boxes to stabilize the oxidation state of the metals (APHA, 1998).

\section{Determination of the concentrations of heavy metals in surface water}

Surface water samples, previously acid treated after collection were sub sampled for determination of metal contents by atomic absorption spectrophotometric method using Buck Scientific model 200A Spectrophotometer.All manipulations were carried under controlled conditions to avoid contaminations. The concentrations of metals in the water sample were calculated by the extrapolation of the absorbance of the sample from the calibration curve.

\section{Results And Discussion}

A specific trend was noticed in the distribution of the concentrations of the metals from one location to another. From Table 1, it was observed that there was a gradual decrease in the concentrations of metals from location 3 (PTC) to other locations downstream implying that dilution may have taken place. Locations 1(AGAI) and 2 (AGA2) are upstreamlocations and the concentrations of metals at these locations were lower as compared to others. It was observed from Table 2 that the concentrations of metals were higher during dry season as to the wet season. The lower levels in the wet season may be attributed to dilution, continuous water exchange and sedimentation, 'solution effect' consequent upon a process where ions bound in previous semi-dry land by decaying maorophytes are dissolved as water level increases with inundation of fringing swamp and riparian zones (Welcome, 1986).

Table1: Mean and standard deviation of heavy metal concentrations in surface water from Eleme creeks.

\begin{tabular}{|llllllllllllll}
\multicolumn{10}{c}{ Locations } \\
\hline Metals & 1 & 2 & 3 & 4 & 5 & 6 & 7 & 8 & 9 & 10 & $\mathrm{x}+\mathrm{SD}$ \\
$\mathrm{Cd}$ & 0.002 & 0.002 & 0.006 & 0.005 & 0.003 & 0.003 & 0.003 & 0.003 & 0.002 & 0.001 & $0.0033+0.019$ \\
$\mathrm{Cr}$ & 0.018 & 0.032 & 0.257 & 0.208 & 0.301 & 0.287 & 0.269 & 0.147 & 0.108 & 0.100 & $0.172+0.132$ \\
$\mathrm{~Pb}$ & 0.015 & 0.034 & 0.152 & 0.071 & 0.066 & 0.058 & 0.056 & 0.047 & 0.042 & 0.030 & $0.057+0.067$ \\
$\mathrm{Fe}$ & 0.179 & 0.165 & 0.684 & 0.538 & 0.473 & 0.405 & 0.458 & 0.391 & 0.371 & 0.368 & $0.403+0.197$ \\
$\mathrm{Zn}$ & 0.097 & 0.094 & 0.306 & 0.243 & 0.253 & 0.208 & 0.238 & 0.290 & 0.215 & 0.238 & $0.218+0.181$ \\
$\mathrm{Ni}$ & 0.128 & 0.155 & 1.812 & 1.459 & 1.387 & 1.090 & 0.963 & 0.908 & 0.386 & 0.364 & $0.865+0.816$ \\
$\mathrm{Mn}$ & 0.266 & 0.738 & 1.445 & 1.328 & 1.183 & 0.616 & 0.601 & 0.383 & 0.366 & 0.325 & $0.725+0.475$ \\
$\mathrm{Cu}$ & 0.003 & 0.008 & 0.025 & 0.021 & 0.023 & 0.013 & 0.010 & 0.008 & 0.005 & 0.004 & $0.011+0.014$
\end{tabular}

Table2 : Seasonal Mean and range of heavy metals concentrations $(\mathrm{mg} / \mathrm{l})$ in surface water from Eleme creeks

Wet Season

$\begin{array}{ll}\text { Metals } & \text { Mean } \\ \mathrm{Cd} & 0.002 \\ \mathrm{Cr} & 0.180 \\ \mathrm{~Pb} & 0.046 \\ \mathrm{Fe} & 0.324 \\ \mathrm{Zn} & 0.084 \\ \mathrm{Ni} & 0.441 \\ \mathrm{Mn} & 0.671 \\ \mathrm{Cu} & 0.005\end{array}$

$\begin{array}{ll}\text { Range } & \text { Mean } \\ 0.0001-0.0070 & 0.004 \\ 0.0010-0.4310 & 0.166 \\ 0.0004-0.7390 & 0.068 \\ 0.0630-0.7610 & 0.482 \\ 0.0197-0.2140 & 0.035 \\ 0.0080-1.1340 & 1.338 \\ 0.0491-1.8691 & 0.779 \\ 0.0011-0.0087 & 0.019\end{array}$

Dry Season

$\begin{array}{ll}\text { Mean } & \text { Range } \\ 0.004 & 0.0010-0.0080 \\ 0.166 & 0.0220-0.4290 \\ 0.068 & 0.0130-0.4370 \\ 0.482 & 0.0870-0.8400 \\ 0.035 & 0.1140-0.6990 \\ 1.338 & 0.0610-2.8590 \\ 0.779 & 0.0213-1.6892 \\ 0.019 & 0.0024-0.0630\end{array}$

\section{Cadmium}

The mean concentration of cadmium in surface water with standard deviation was $0.003+0.019 \mathrm{mg} / \mathrm{l}$. The lowest concentration of $0.001 \mathrm{mg} / \mathrm{l}$ was recorded at location $10(0 \mathrm{KR})$ and the highest concentration of 
$0.006 \mathrm{mg} / \mathrm{l}$ was obtained at location 3 (PTC) as shown in Table 1 . The mean concentration in the wet season was $0.002 \mathrm{mg} / 1$ while that in the dry season was $0.004 \mathrm{mg} / 1$ (Table 2). Results of the 2-way ANOVA revealed that there was a significant variation between the sampling points and sampling periods implying variations in the distribution of $\mathrm{Cd}$ concentrations at different sampling points and sampling periods consequent upon variable factors that may have affected the concentrations. The levels of cadmium obtained in this study are similar to those obtained in some Nigerian rivers (Mahreet al.,2007; Benson and Etesin, 2008). The concentrations of cadmium are also within the maximum permissible limit of $0.03 \mathrm{mg} / \mathrm{l}$ (WHO, 2003) and less than $1.0 \mathrm{~m} / 1$ by (FEPA, 1991). A comparison of the results obtained in this study with those by others revealed that cadmium levels in the Niger Delta are within the levels recommended by the regulating authority in Nigeria and those of international bodies. Cadmium even in small concentrations may be toxic. At high levels, the liver and kidneys are target organs, while at lower concentrations, the pancreas and spleen may be affected.

\section{Chromium}

The mean concentration recordedfor chromium in surface water was $0.172 \mathrm{mg} / \mathrm{l}$ and the standard deviation was $0.132 \mathrm{mg} / \mathrm{l}$. The lowest concentration of $0.018 \mathrm{mg} / \mathrm{l}$ was found at location 1 (AGA 1) while the highest concentration of $0.301 \mathrm{mg} / \mathrm{l}$ was obtained at location 5 (SLR). The concentration of chromium in the dry season was $0.166 \mathrm{mg} / \mathrm{l}$ while $0.180 \mathrm{mg} / \mathrm{l}$ was the concentration in the wet season (Table 2). Results of the 2-way ANOVA show that there was a significant variation in the concentrations of $\mathrm{Cr}$ between locations and months of sampling. FEPA (1991) recommended level for chromium is less than $1.0 \mathrm{~m} / 1$. The recommended limit for chromium in effluents from petrochemicals manufacturing is $0.1 \mathrm{mg} / \mathrm{l}$ (World Bank, 1990). A Comparison of the levels obtained from this study with those obtained by others reveals that $\mathrm{Cr}$ concentrations are within level stipulated by the regulating authority in Nigeria. The highest concentration of chromium at location 5 (STR) may be attributed to the wastes generated from the slaughter in addition to the input from the Petrochemicals Company. In animals' studies, chromium was found to accumulate mainly in liver, kidneys, spleen and bone marrow after both oral and paternal administration of different compounds. In humans, the highest concentrations are found in hilar humph nodes and lungs, followed by spleen, liver, and kidneys (Janus and Kranjc, 1990). Ingestion of 1-5g of "chromate" may results in severe acute effects such as gastrointestinal disorders, haemorrhagic diathesis, and convulsions.

\section{Lead}

The obtained mean concentration of lead in surface water was $0.057 \mathrm{mg} / \mathrm{l}$ while the standard deviation was $0.067 \mathrm{mg} / \mathrm{l}$. It was observed that the lowest mean concentration of $0.015 \mathrm{mg} / 1$ was obtained at location 1 (AGA1) while the highest concentration of $0.152 \mathrm{mg} / 1$ was obtained at location 3 (PTC) as shown in Table 1 . Results of analyses show that the mean concentration of $\mathrm{Pb}$ obtained in the wet season was $0.0046 \mathrm{mg} / \mathrm{l}$ while that in the dry season was $0.067 \mathrm{mg} / \mathrm{l}$ (Table 2). Results of the 2-way ANOVA show that there was a significant variation in the concentration of lead between sampling points and the periods of sampling. The levels of lead obtained in this study are considerably similar to those obtained for Iko River in Akwalbom state (Benson and Etesin, 2008). FEPA (1991) recommended level of lead in surface water is less than $1.0 \mathrm{mg} / \mathrm{l}$ while $0.01 \mathrm{mg} / \mathrm{l}$ is recommended by (WHO, 1984; ANZECC, 2000). The results obtained from this study are in good agreement with Nigeria recommended limits. It was observed that there was a gradual decrease in the concentrations of this metal from location 3 (PTC) downstream to location 10 (OKR). This shows that there was gradual dilution of $\mathrm{Pb}$ concentrations as the water flows from the point source (PTC) downstream. In addition to the increase in concentrations of lead which is presumed to come from the Petrochemicals Company, surface run-off containing other materials such as paint pigments from spraying workshops close by and metal fuel additives are potential contributing factors (Ibok et al., 1989; Kokovides et al., 1992). Leachates from domestic wastes and even those from surface sediments during wet season are good contributors. Early symptoms of lead poisoning in adults are commonly nonspecific and include depression, loss of appetite, abdominal pain, nausa, diarrhea and constipation (Merrill et al., 2007).

\section{Iron}

The mean concentration of iron in surface water with standard deviation was $0.403+0.197 \mathrm{mg} / \mathrm{l}$. The lowest concentration of $0.165 \mathrm{mg} / \mathrm{l}$ was obtained at location 2 (AGA2) while the highest concentration of $0.684 \mathrm{mg} / 1$ was obtained at location 3 (PTC) (Table 1). The levels of iron in the wet and dry season were $0.324 \mathrm{mg} / \mathrm{l}$ and $0.482 \mathrm{mg} / \mathrm{l}$ respectively (Table 2). Results of the 2-way ANOVA show that there was a significant difference in the concentrations of iron between the sampling locations and the periods of sampling. Eleme petrochemicals EIA (1992) gaves a concentration of iron of $0.69 \mathrm{mg} / \mathrm{l}$ in Eleme water. The results obtained from the study are within recommended levels. Iron is an essential element in humans forming part of hemoglobin, myoglobin and enzymes. The element is estimated to be $60-70 \mathrm{mg} / \mathrm{g}$ in humans. Iron and manganese are found in relatively high concentrations in fresh water ecosystems, and in many respects can be 
viewed as 'master metal' owing to their ability to influence the cycles of other biologically important elements through both microbial mediated and abiotic reaction Giblin (2009). However, exposure to excess levels of iron greater than $50-100 \mathrm{mg} /$ day may result in pathological deposition of iron in the body tissues, the symptoms of which are fibrosis of pancreas, diabetes mellitus and liver cirrhosis (Richard, 1996).

\section{Zinc}

The recorded mean concentration for zinc in surface water with standard deviation was $0.218+$ $0.181 \mathrm{mg} / \mathrm{l}$. The lowest concentration of $0.094 \mathrm{mg} / \mathrm{l}$ was obtained at location2 (AGA2) while the highest concentration of $0.306 \mathrm{~m} / 1$ was obtained at location 3 (PTC) as shown in Table 1 . The mean concentration of zinc in the surface water during wet season was $0.084 \mathrm{mg} / 1$ while that in the dry season was $0.0351 \mathrm{mg} / 1$ (Table 2). Results of the 2-way ANOVA show that there was a significant variation in the concentration of zinc between the sampling locations and sampling periods. The Petrochemicals Company EIA (1992) gave the concentration of zinc as $0.26 \mathrm{mg} / \mathrm{l}$ in water at Eleme while FEPA (1991) gives the permissible limit in the concentration of zinc in water to be less than $1.0 \mathrm{mg} / \mathrm{l}$. The zinc concentration for United States drinking water varies between 0.06 and $7.0 \mathrm{mg} / \mathrm{l}$ with a mean of $1.33 \mathrm{mg} / 1$.

The concentrations of zinc obtained from the study are within the recommended range. The dredging and the slaughtering activities around locations 4 and 5 may have contributed to the elevated concentrations recorded at these points. Surface runoff as a result of zinc plating of steel, batteries and alloy, such as brass in the surrounding environment may have contributed to reasonable amount of zinc in the creeks. Zinc most commonly enters the domestic water supplies from deterioration of galvanized iron and dezincification of brass. Although zinc is a very essential requirement for a healthy body, excess zinc can be harmful, and cause zinc toxicity (Formire, 1990).

\section{Nickel}

The obtained mean concentration for nickel in surface water was $0.816 \mathrm{mg} / \mathrm{l}$ while the standard deviation was $0.816 \mathrm{mg} / \mathrm{l}$. The lowest concentration of $0.128 \mathrm{mg} / \mathrm{l}$ was obtained at location I (AGAI) while the highest concentration of $1.812 \mathrm{mg} / \mathrm{l}$ was obtained at location3 (PTC). Results of the study also show that the concentration of nickel in the wet season was $0.441 \mathrm{mg} / \mathrm{l}$ while a concentration of $1.338 \mathrm{mg} / \mathrm{l}$ was recorded during the dry season (Table 2). Results of the two-way ANOVA indicate that there was a significant variation in the mean concentrations of nickel between the sampling points and sampling periods. The limitation for nickel in surface water in Nigeria is less than 1.0mg/l (FEPA, 1991). Concentrations of nickel obtained from the study are within the regulating limits in the country except at location 3 (PTC). The slight increase obtained at location 3 may be attributed to wastewaters/effluents from the Petrochemicals Company consequent upon catalytic hydrogenation processes that use $\mathrm{Ni}$ or its compounds as catalysts. Nickel is essential to health in animals. Although lack of nickel has not been found to affect the health of humans, a small amount of nickel is probably also essential for humans. Levels of nickel very much greater than the levels normally found in food cause lung disease in dogs and rats and affect the stomach, blood, liver, kidneys, and immune system in rats and mice.

\section{Manganese}

The mean concentration of manganese in surface water was $0.725 \mathrm{mg} / \mathrm{l}$ and the standard deviation was $0.475 \mathrm{mg} / \mathrm{l}$. The lowest concentration of $0.226 \mathrm{mg} / \mathrm{l}$ was obtained at location I (AGA I) while the highest concentration of $1.812 \mathrm{mg} / \mathrm{l}$ was obtained at location 3 (PTC), (Table 1). The mean concentration obtained in the wet season was $0.671 \mathrm{mg} / 1$ and that in the dry season was $0.779 \mathrm{mg} / 1$ (Table 2). Results of the 2- way ANOVA indicate a significant variation in the mean concentrations of Mn between the sampling locations but there was no significant difference in the mean concentrations of $\mathrm{Mn}$ in the various months. The recommended level of manganese in surface water is 5.0mg/l (FEPA, 1991). The Eleme Petrochemical Company EIA (1992) gave the concentration of manganese obtained from Eleme water to be less than $0.01 \mathrm{mg} / \mathrm{l}$. A Comparison of the results obtained from this study with those obtained from the EIA study reveals that manganese concentration has increased considerably, although it is not more than that stipulated by the regulating authority in Nigeria. Manganese has been noted to be less toxic than those of other widespread metals such as copper (Hassan, 2008). Higher levels of manganese in drinking water are associated with increased intellectual impairment and reduced intelligence quotients in school-age children (Bouchard et al., 2010).

\section{Copper}

The mean concentration of copper in surface water with standard deviation was $0.011+0.014 \mathrm{mg} / \mathrm{l}$. Results obtained from the study show that the lowest mean concentration of $0.003 \mathrm{mg} / \mathrm{l}$ was obtained at location 1 (AGA I) while the highest concentration of $0.025 \mathrm{mg} / \mathrm{l}$ was obtained at location 3 (PTC). Mean concentration of $0.005 \mathrm{mg} / \mathrm{l}$ was obtained in the wet season while mean concentration of $0.0198 \mathrm{mg} / \mathrm{l}$ was 
obtained during the dry season (Table 2). It was found from the results of the 2-way ANOVA that there was a significant difference between the mean concentrations of $\mathrm{Cu}$ between the sampling locations and the sampling periods. The maximum level of copper in liquid effluents from the Petrochemicals Company is $0.5 \mathrm{mg} / \mathrm{l}$ (World Bank, 1990). The Eleme Petrochemicals Company EIA (1992) result on water analysis for $\mathrm{Cu}$ was $0.1 \mathrm{mg} / \mathrm{l}$. The U.S. Environmental Protection Agency's maximum contaminate level (MCL) in drinking water is $1.3 \mathrm{mg} / \mathrm{l}$.

A comparison of the results obtained from this study with those of the regulating body in Nigeria and the EIA results reveals that the level of copper is within acceptable limits. Copper toxicity can occur from eating acid food that has been cooked in uncoated copper cookware or from exposure to excess copper in drinking water or other environmental sources. Chronic (long-term exposure) copper exposure can damage the liver and kidneys (ARD-EHP-9, 2005).

\section{Conclusion}

An examination of the concentrations and toxic effects of some heavy metals in surface water from the Niger Delta, Nigeria were carried out. It was discovered from the results of the investigation that the levels of these metals were still within the national and international recommended limits. However, these metals are known to be very toxic on the health of humans and aquatic habitat even at trace amount. Based on increasing levels of these metals in surface water, it is necessary that the companies operating within this place give adequate treatment to the generated wastes before discharging them.

\section{References}

[1]. ANZECC (2000). Australian and New Zealand guidelines for fresh and marine water quality. Austrilian and New Zealand environment and conservation council

[2]. APHA (1998). Standard Method for examination of water and wastewater. $20^{\text {th }}$ Edition. American Public Health Association, American Water Works Association and Water Environmental Fedration (APHA-AWWA-WEF), Published by the American Public Health Association, Washington D.C.

[3]. ARD-EHP-9 (2005). "Copper". Health Information Summary, Environmental Fact sheet. New Hempshire Department of Environmental Services.

[4]. Benson, B.U. \&Etesin, U.M. (2008). Metal contamination of surface water, sediments and Tympanotusfiscatusradular of Iko River and environmental impact due to Utapete gas flare station. Nigeria Environmentalist 28:195-202.

[5]. Biney, C., Amuzu, A.T., Calamari, D., Kaba, N., Mbome, I.L., Naeve, H., Ochumba, P.B.O., Osibanjo, O., Radegonde, V. \&Saad, M.A.H. (1994). Review of heavy metals in the African Aquatic Environment. Ecotoxicology and Environmental Safety 28:134159.

[6]. Binning, K. \& Baird, D. (2001). Survey of heavy metals in the sediments of Swartkops River estuary, Port Elizabeth, South Africa Water South Africa 27 (4): 461-466

[7]. Bouchard, M.F., Sebastian, S. \& Benoit, B. (2010). Intellectual impairment in school-age children. Environmental Health Perceptive, U.S.A. http: // www.cityofmadion.com / water / waterquality / document/ett.20/0020.Mn/0.pdf.

[8]. Eleme Petrochemicals Company Environmental Impact Assesment study (1992)

[9]. FEPA (1991).Federal Environmental Protection Agency: National Interim Guidelines and Standards for industrial effluents, gaseous emissions and hazardous waste management in Nigeria. Garki, F.C.T; Abuja Nigeria.

[10]. Formire, G.J. (1990). Zinc toxicity. American Journal of Clinical Nutrition 51 (2): 225-227.

[11]. Giblin, A.E. (2009). Encyclopedia of inland waters. Elsevier Science Publishers, South Africa.

[12]. Hasan, H. (2008) Manganese. The Rosen publishing Group, New York, U.S.A.

[13]. Hirner, A.V. \&Hippler J. (2011). Trace metal(loids) and their species. Treatise on Water Science (3) $31-57$.

[14]. Ibok, U.J., Udosen, E.D. \&Udoidong, O.M. (1989). Heavy metals in fishes from some streams in IkotEkpene area of Nigeria. Nigeria Journal of Technical Research 1:61-68.

[15]. Janus, J.A. \&Kranjc, E.I. (1990). Integrated criteria document chromium: effect. Bilthoven, Netherlands national institute of public health and environmental protection.

[16]. Kokovides, K., Loizidou, M. \&Moropoulou, T. (1992). Environmental study of the marinas. Part. 1. A study on the pollution of the marinas area. Environmental Technology 13:239-331.

[17]. Kurdland, L.T. (1960). Minamata disease: Outbreak of neurological disorder in Minamata. Vapour and its relation to ingestion of seafood containing mercury compounds. World Neurology Food Safety 7:177-2001.

[18]. Mahre, M.Y., Akan, J.C., Moses, E.A. \&Ogugbuaja, V.O.(2007). Pollution indicators in River Kaduna, Kaduna State, Nigeria. Trends in Applied Science Research 2(4):304-311.

[19]. Merrill, J.C., Morton, J.J.P. \&Soileau, S.D. (2007). "Metals" In Hayes, A.W. Principles and Methods of Toxicology. 5" edition. CRC Press, U.S.A.

[20]. Onuoha, P.B. (1996). Heavy metals content of the urine of inhabitants of oil producing communities in Rivers State. M.Sc Thesis, Department of Chemistry, University of Port Harcourt, Nigeria.

[21]. Opuene, K. (2004). Water quality levels and impacts of heavy metals and polycyclic aromatic hydrocarbons in the Taylor Creek Aquatic Ecosystem, Bayelsa State, Nigeria. Ph.D Thesis of the University of Nigeria, Nsukka, Nigeria.

[22]. Richard, J.L. (1996). Sax's dangerous properties of industrial materials. $9^{\text {th }}$ Edition. New York. Van Monstrand Reinhold Publishers.

[23]. W.H.O (2003). The world health report, 2003: Shaping the future World Health Organization 1211 Geneva 27, Switzerland

[24]. W.H.O. (1984). Guidelines for drinking water quality. Volume 2. Health Criteria and other supporting information. W.H.O; Geneva.

[25]. Welcome, R.L. (1986). The Niger River system. Longman Group Ltd, London.

[26]. World Bank (1990). The petrochemicals industry in developing Asia: A review of the current situation and prospects for development in the 1990s by Walter Vergara and Dominique Babelon. World Bank Technical Paper Number 113, Industry and Energy Series, Washington, D.C. 